\title{
Penataan Ruang Kawasan Pantai Selatan Daerah Istimewa Yogyakarta Sebagai Mitigasi Terhadap Bencana Banjir Rob
}

\author{
Achmad Andi Rif' an dan Novi Irawati \\ Program Studi S1 Pariwisata, Sekolah Tinggi Pariwisata Ambarrukmo (STIPRAM) Yogyakarta \\ e-mail: andi.stipram@gmail.com
}

\begin{abstract}
Abstrak - Pantai Selatan Daerah Istimewa Yogyakarta (DIY) memiliki potensi pariwisata yang berpengaruh pada perkembangan perekonomian masyarakat. Akan tetapi, kawasan tersebut juga mempunyai ancaman bencana. Terjadinya banjir rob memberikan dampak negatif kepada perkembangan pariwisata sehingga sangat penting dilakukan penataan ruang berbasis pengurangan risiko bencana. Konsep Abad Samudera Hindia yang merupakan gagasan dan visi program dari Sri Sultan Hamengku Buwono $X$ untuk menjadikan pantai selatan sebagai pintu gerbang pariwisata juga menjadi landasan dari penelitian ini. Penelitian ini bertujuan untuk (1) mengidentifikasi bahaya (hazard) bencana banjir di kawasan Pantai Selatan DIY; (2) penguatan konsep pengembangan pariwisata; (3) penataan ruang kawasan pantai selatan berbasis mitigasi bencana. Penataan ruang kawasan pantai dilakukan secara bertahap. Tahap pertama adalah memetakan dan memodelkan kejadian banjir rob di kawasan pantai. Tahap kedua adalah evaluasi data tata ruang kawasan pesisir dengan metode analisis SWOT. Tahap ketiga menyusun zonasi penataan ruang kawasan pantai. Hasil penelitian ini adalah peta yang menunjukkan bagian dari kawasan Pantai Baru dan Pantai Kuwaru yang terkena dampak dari banjir rob yang selanjutnya diberikan rekomendasi pemanfaatan ruang yang membagi kawasan pantai menjadi 3 bagian yaitu zona I (Zona Pemanfaatan Terbatas), zona II (Zona Utama Wisata), dan Zona III (Zona Pengembangan Wisata).
\end{abstract}

Kata Kunci- Mitigasi Bencana; Penataan Ruang; Pengembangan Pariwisata

\section{PENDAHULUAN}

$\mathrm{I}$ NDONESIA merupakan negara yang memiliki potensi wilayah pesisir yang besar. Potensi wilayah pesisir diantaranya dapat dimanfaatkan untuk kawasan wisata pantai [1]. Wisata pantai merupakan jenis wisata alam yang banyak dinikmati wisatawan. Akan tetapi, negara ini juga mengalami banyak kejadian bencana dan krisis yang mengancam performa perekonomian termasuk pariwisata [2][3]. Daerah Istimewa Yogyakarta (DIY) merupakan salah satu provinsi di Indonesia yang memiliki banyak daya tarik wisata pantai yang tersebar di 3 kabupaten yaitu Kabupaten Gunung Kidul, Kabupaten Bantul, dan Kabupaten Kulon Progo dengan total panjang garis pantai 126 kilometer [4]. Akan tetapi, kawasan tersebut juga mempunyai ancaman bencana yaitu banjir rob [2]. Banjir rob menjadi ancaman serius bagi kawasan pantai selatan DIY karena dapat menyebabkan kerusakan pada permukiman, fasilitas umum, dan daya tarik wisata [5]. Terjadinya banjir rob memberikan dampak negatif kepada perkembangan pariwisata di kawasan tersebut.

Di sisi lain, rencana Gubernur Provinsi DIY yang menjadikan Samudera Hindia sebagai tema dan payung berpikir dalam perumusan arah pembangunan Daerah Istimewa Yogyakarta, membuat kawasan pesisir selatan menjadi kawasan prioritas untuk dikembangkan. Samudera Hindia merupakan kawasan strategis, tidak hanya bagi Indonesia tetapi juga bagi seluruh dunia, di mana lalu lintas perdagangan sejak zaman dahulu banyak melewati kawasan ini. Saat ini jalur Samudera Hindia banyak digunakan untuk pelayaran kapal kontainer dunia, sepertiga lalu lintas kargo, dan dua pertiga pengiriman minyak dunia [6]. Selain itu jalur Samudera Hindia menjadi kawasan strategis karena menjadi tempat tinggal bagi 2,6 miliar penduduk atau dua perlima jumlah penduduk dunia [6].

Pantai Selatan DIY memiliki potensi pariwisata yang sangat berpengaruh pada perkembangan perekonomian masyarakat. Akan tetapi, kawasan tersebut juga mempunyai ancaman bencana. Terjadinya banjir rob dan abrasi pantai memberikan dampak negatif kepada perkembangan pariwisata khususnya dipesisir selatan. Pentingnya dilakukan konsep penataan ruang kawasan untuk mengurangi dampak yang ditimbulkan. Konsep menyongsong abad Samudera Hindia yang merupakan gagasan dari Sri Sultan Hamengku Buwono X yang disampaikan dalam pidato penyampaian visi program gubernur melalui rapat paripurna untuk menjadikan pantai selatan sebagai pintu gerbang pariwisata. Secara eksplisit, esensi dari abad Samudera Hindia yang nantinya akan diletakkan sebagai tema dan payung berfikir dalam perumusan arah pembangunan DIY dalam 5 tahun ke depan.

Pantai Kuwaru dan Pantai Baru merupakan daya tarik wisata pantai baru di kawasan pantai selatan DIY yang juga terletak di jalur Samudera Hindia. Kedua pantai tersebut lokasinya berdekatan dan berada pada satu kawasan di Kabupaten Bantul. Wisatawan, baik yang berasal dari DIY maupun dari luar DIY, banyak yang memilih ketiga pantai tersebut karena masih baru dan alami sebagai alternatif dari pantai-pantai lain yang ada di DIY. Akan tetapi, pantai-pantai tersebut juga mengalami permasalahan berupa bencana banjir rob yang telah merusak beberapa fasilitas di sekitar pantai. Wilayah pesisir yang dijadikan lokasi wisata bahari menjadi rentan terhadap bencana alam kepesisiran seperti banjir rob, erosi pantai, angin topan, dan gelombang tsunami maupun dampak dari perubahan iklim [7] [8]. 
Berdasarkan latar belakang di atas, diperlukan konsep penataan ruang kawasan pantai selatan DIY untuk mengurangi dampak yang ditimbulkan dari bencana yang terjadi sekaligus untuk menguatkan visi misi Gubernur DIY yang menjadikan kawasan Samudera Hindia sebagai arah pembangunan. Penelitian ini bertujuan untuk (1) mengidentifikasi bahaya (hazard) bencana banjir di kawasan Pantai Selatan DIY; (2) analisis pengembangan pariwisata; (3) Penataan ruang kawasan pantai selatan DIY.

\section{METODE PENELITIAN}

\section{A. Data Penelitian}

Data yang digunakan dalam penelitian ini meliputi data penginderaan jauh untuk mengetahui penggunaan lahan serta kerusakan wilayah pesisir akibat banjir rob, data kejadian bencana banjir rob, dan data tata ruang kawasan pesisir Kabupaten Bantul. Penataan ruang kawasan pantai dilakukan secara bertahap. Tahap pertama adalah memetakan dan memodelkan kejadian banjir rob di kawasan pantai. Tahap kedua adalah evaluasi data tata ruang kawasan pesisir dengan metode analisis SWOT. Tahap ketiga menyusun zonasi penataan ruang kawasan pantai.

\section{B. Metode Analisis}

Jenis penelitian ini berdasarkan rumusan masalah serta tujuan penelitian yaitu sifatnya deskriptif kualitatif [9]. Sesuai dengan tujuan yang ingin dicapai dan dari penelitian ini, maka teknik analisis data yang dilakukan adalah sebagai berikut:

\section{- Synoptic Planning Method}

Pendekatan ini bersifat rasional dan komprehensif, serta memiliki langkah-langkah penentuan rekomendasi penataan kawasan yang sistematis. Terdapat beberapa tahapan yang dilakukan pada synoptic planning method ini, antara lain: data collection (pengumpulan data melalui survey/observasi kondisi eksisting Kawasan); data analysis (identification of all opportunities and limitation); generations of alternative concepts (generalisasi beberapa alternatif konsep); dan translation solutions into plans and guidelines (mengaplikasikan konsep menjadi rencana dan arahan).

- Pemetaan Banjir Rob

Analisis genangan banjir rob dilakukan melalui software Geographycal Information System (GIS). Analisis ini dilakukan untuk mengetahui tingkat bahaya dan sebaran dari bencana banjir rob terhadap aktivitas pariwisata di kawasan wisata pantai selatan Kabupaten Bantul, yaitu Pantai Baru dan Pantai Kuwaru. Pemetaan genangan banjir rob melalui beberapa tahapan seperti terlihat pada Gambar 1.

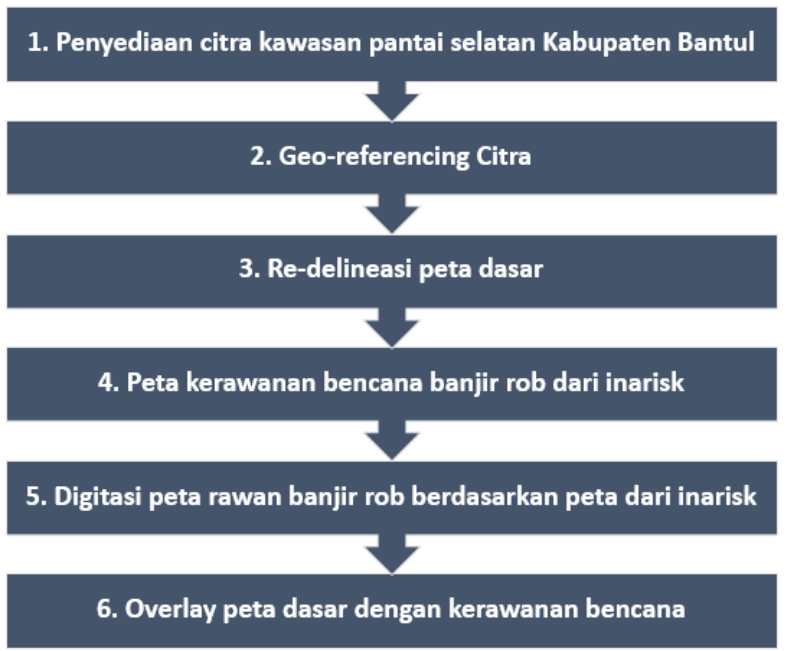

Gambar 1. Langkah-Langkah Pemetaan Bahaya Genangan dari Inarisk

\section{- Analisis Pengembangan Kawasan}

Analisis SWOT adalah analisis untuk mengidentifikasi berbagai faktor secara sistematis untuk merumuskan strategi [10]. Analisis ini secara logika dapat memaksimalkan kekuatan (Strength) dan peluang (Opportunity) namun secara bersamaan dapat meminimalkan kelemahan (Weakness), dan ancaman (Threat). Proses pengambilan keputusan strategis selalu berkaitan dengan pengembangan misi, tujuan, strategi, dan kebijakan.

Tabel 1.

Metode Analisis SWOT

\begin{tabular}{ccc}
\hline \hline Internal/Eksternal & Strength & Weakness \\
\hline Opportunity & S - O & W - O \\
\hline Threat & S - T & W - T \\
\hline \hline
\end{tabular}

\section{PEMBAHASAN}

\section{A. Profil Kawasan}

\section{- Tata Guna Lahan}

Distribusi tata guna lahan di dalam kawasan terbagi menjadi dua kategori; kategori natural environment, dan kategori build environment. Kategori natural environment meliputi bentang lahan pertanian, hutan lindung, dan pesisir pantai, sedangkan kategori lahan terbangun meliputi fungsi perdagangan/komersial, permukiman, peribadatan, pelayanan \& perkantoran, pertanian \& perikanan, serta pembangkit listrik tenaga bayu, di mana fungsi perdagangan/komersial adalah yang paling dominan. Kondisinya sebagian besar fasilitas yang ada kurang terawat dan banyak mengalami kerusakan akibat abrasi. Di kawasan Pantai Kuwaru banyak fasilitas yang tidak lagi digunakan karena terjadi penurunan tingkat kunjungan wisatawan. Namun, untuk Kawasan pantai Baru justru mengalami peningkatan dan ramai pengunjung. Hal ini terjadi karena adanya pergeseran minat wisatawan untuk mengunjungi kawasan pantai Kuwaru yang mengalami kerusakan yang cukup signifikan dari daya tarik pantainya dan juga fasilitas yang ada dikawasan tersebut. Peta tata guna lahan di kawasan Pantai Baru dan Pantai Kuwaru dapat dilihat pada Gambar 2. 


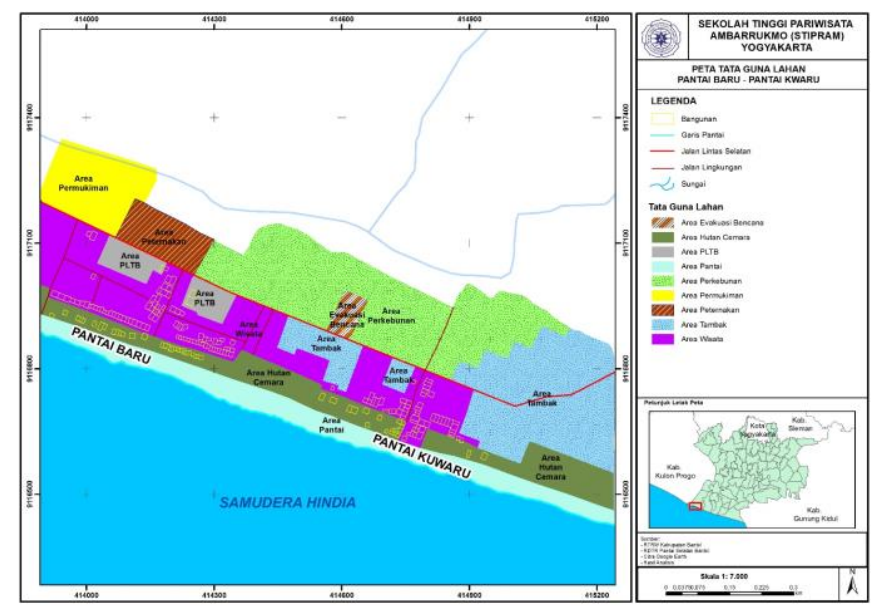

Gambar 2. Peta Tata Guna Lahan di Kawasan Pantai Baru dan Pantai Kuwaru

\section{- Aksesibilitas}

Jejaring aksesibilitas kawasan meliputi jalan utama yang menghubungkan beberapa destinasi wisata pantai serta jejaring jalan di dalam masing-masing Kawasan Pantai Kuwaru dan Pantai Baru. Fasilitas pendukung aksesibilitas di dalam kawasan berupa jalan dengan finishing aspal, paving, dan jalan setapak, dan didukung beberapa titik kantung parkir. Untuk mencapai kedua kawasan tersebut dapat melalui jalan arteri primer yaitu Jaringan Jalan Lintas Selatan Yogyakarta (JJLS) yang sudah dikembangkan oleh pemerintah. Yang terhubung dengan jalan kolektor primer yaitu Jln Bantul - Srandakan Toyan, Jln Srandakan - Kretek \& Jln Palbapang - Samas. Aksesibilitas di Pantai Baru dan Pantai Kuwaru dapat dilihat pada Gambar 3.

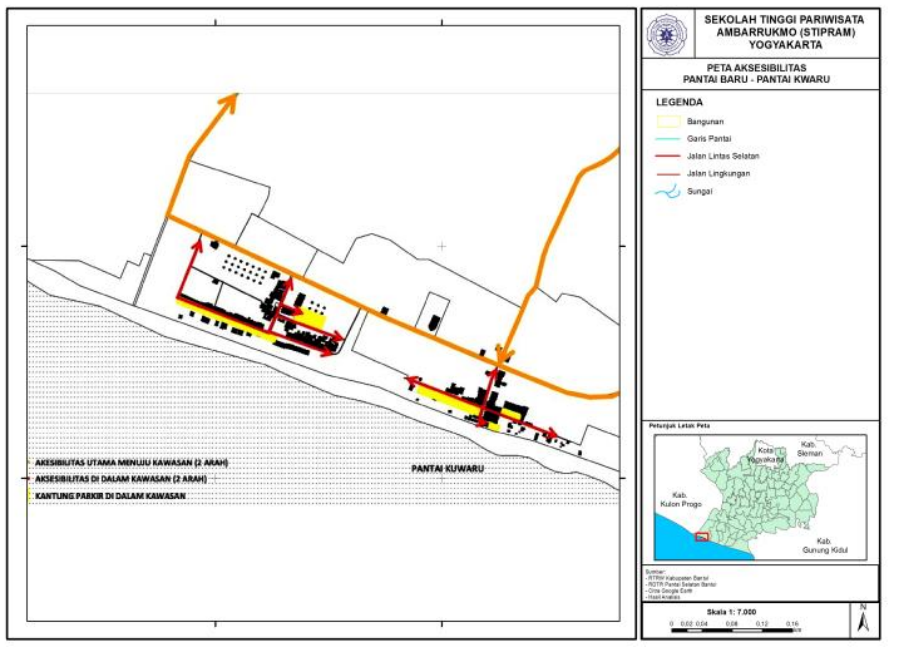

Gambar 3. Peta Aksesibilitas di Kawasan Pantai Baru dan Pantai Kuwaru

- Ruang Terbuka Hijau dan Preservasi

Lingkup area ruang terbuka hijau di dalam kawasan cukup luas dengan bentang lahan pertanian menjadi yang paling dominan. Ruang terbuka hijau yang berada di dalam kawasan Pantai Kuwaru dan Pantai Baru berupa hutan cemara yang sekaligus difungsikan sebagai ruang terbuka publik bagi wisatawan.

Area preservasi pada kawasan Pantai Kuwaru dan Pantai Baru merupakan bentang ruang hijau hutan cemara. Lingkup area preservasi ini membentang di sepanjang pesisir Pantai Baru dan Pantai Kuwaru dan dengan pantai yang lain di sepanjang pesisir pantai selatan kabupaten Bantul. Kondisi ruang terbuka hijau dan preservasi di Pantai Baru dan Pantai Kuwaru dapat dilihat pada Gambar 4.

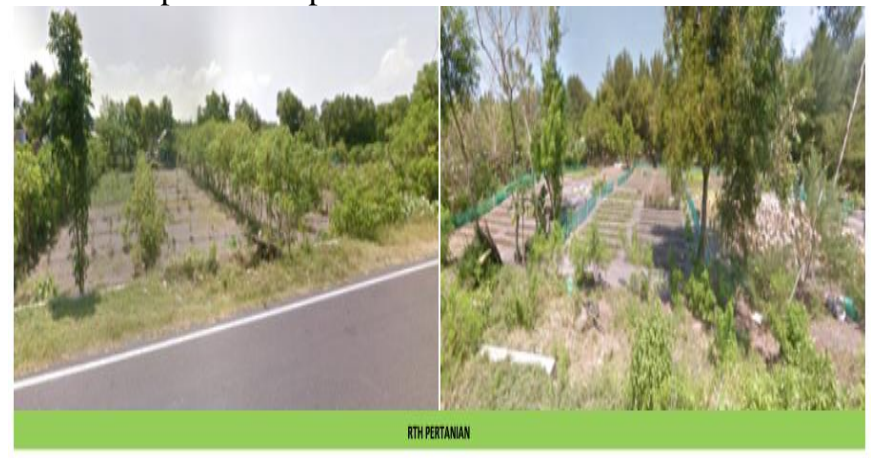

Gambar 4. Kondisi Ruang Terbuka Hijau dan Preservasi di Kawasan Pantai Baru dan Pantai Kuwaru

\section{B. Pemetaan Genangan Banjir Rob}

Konsep manajemen wisata alam, salah tidak boleh hanya fokus pada jumlah pengunjung demi keuntungan ekonomi tetapi juga kelestarian lingkungan sehingga memberi manfaat kepada masyarakat sekitarnya karena dampak negatif wisata alam justru dapat menyebabkan degradasi ekosistem [2] [11]. Wilayah pesisir Pantai Baru dan Pantai Kwaru yang berada di Kecamatan Srandakan, Kabupaten Bantul, merupakan wilayah pesisir yang sangat dinamis. Berbagai macam proses dinamika pantai terjadi di sini. Baik yang terjadi secara alami karena pengaruh angin, gelombang dan arus maupun proses yang terjadi karena campur tangan manusia. Proses-proses tersebut meliputi erosi pantai atau abrasi, sedimentasi, gelombang ekstrim, dan banjir rob.

Proses erosi pantai telah menyebabkan perubahan garis pantai di mana garis pantai mengalami kemunduran. Perubahan garis pantai telah menimbulkan banyak kerugian bagi masyarakat yang tinggal di wilayah pesisir. Garis pantai yang semakin mundur dan mendekati permukiman warga menyebabkan air laut mengenai permukiman dan lahan penduduk saat terjadi pasang atau yang lebih dikenal dengan istilah "banjir rob".

Pantai Baru dan Pantai Kwaru adalah salah satu daya tarik wisata pantai di Kabupaten Bantul yang telah mendatangkan cukup banyak wisatawan. Ketika terjadi banjir rob, fasilitas wisata maupun atraksi yang ada di kedua pantai tersebut terdampak dan mengalami genangan.

Langkah-langkah yang dilakukan dalam pemetaan genangan banjir rob di Pantai Baru dan Pantai Kuwaru adalah sebagai berikut:

1. Penyediaan citra kawasan pantai selatan Kabupaten Bantul

Analisis sebaran genangan banjir rob Pantai Baru dan Pantai Kuwaru dimulai dari mengunduh citra kawasan pantai selatan Kabupaten Bantul. Citra kawasan pantai selatan terbaru dibutuhkan untuk mengetahui kondisi terkini dari Pantai Baru dan Pantai Kuwaru terutama setelah mengalami banjir rob. Citra kawasan pantai selatan diunduh dari software Google Earth Pro, yaitu sebuah perangkat lunak open source yang menyediakan citra di seluruh permukaan bumi. Citra yang didapat adalah citra kawasan Pantai Baru dan Pantai Kuwaru 
tahun 2018 .

\section{Geo-referencing Citra}

Setelah mengunduh citra, langkah selanjutnya adalah melakukan proses georeferencing, yaitu proses pemberian referensi geografi atau memberikan suatu sistem koordinat dari data raster yang belum memiliki acuan sistem koordinat ke dalam suatu sistem koordinat. Sistem koordinat yang digunakan adalah UTM. Sistem koordinat UTM atau Transverse Sistem Mecator digunakan karena sistem koordinat ini memungkinkan untuk menghitung luasan suatu wilayah atau objek tertentu juga bisa menghitung jarak dan panjang antara dua objek.

3. Re-delineasi peta dasar

Setelah data raster berupa citra kawasan Pantai Baru dan Pantai Kuwaru diberikan referensi geografis, maka langkah selanjutnya adalah mendigitasi atau mendelineasi peta dasar berupa garis pantai, jalan, dan sungai. Beberapa peta dasar seperti peta administrasi, sungai, dan jalan sebenarnya sudah didapatkan dari dokumen Revisi RTRW Kabupaten Bantul. Akan tetapi karena skalanya adalah skala kabupaten, maka ketika digabung dengan citra maka sedikit melenceng. Maka dari itu perlu didigitasi ulang.

4. Peta kerawanan bencana banjir rob dari inarisk

Peta kerawanan banjir rob didapatkan dari portal inarisk, yaitu sebuah portal yang menyajikan kajian risiko bencana dengan menggunakan arcgis server sebagai data services yang menggambarkan cakupan wilayah ancaman bencana, populasi terdampak, potensi kerugian fisik, potensi kerugian ekonomi, dan potensi kerusakan lingkungan yang terintegrasi dengan realisasi pelaksanaan kegiatan pengurangan risiko bencana sebagai tool monitoring penurunan indeks risiko bencana.

Dalam portal inarisk, terdapat beberapa pilihan bencana seperti gempa bumi, gunung meletus, tsunami, dan lain-lain. Dalam penelitian ini dipilih banjir rob dan area yang dipilih adalah kawasan pantai selatan Kabupaten Bantul, tepatnya di kawasan Pantai Baru dan Pantai Kuwaru.

5. Digitasi peta rawan banjir rob berdasarkan peta dari inarisk

Peta yang didapat dari portal Inarisk berbentuk raster, yang meliputi area Pantai Baru dan Pantai Kuwaru, tetapi sudah memiliki referensi geografis sehingga bisa langsung ditampalkan dengan peta dasar. Langkah selanjutnya adalah mendigitasi ulang peta raster tersebut sehingga menjadi bentuk shapefile dan terlihat lebih jelas area mana saja yang terdampak banjir rob.

6. Overlay peta dasar dengan kerawanan bencana

Langkah selanjutnya adalah melakukan analisis overlay atau tumpang susun antar layer peta. Peta yang di-overlay adalah peta dasar kawasan Pantai Baru dan Kuwaru dengan peta sebaran banjir rob. Hasil dari overlay peta ini menghasilkan peta sebaran banjir rob di kawasan Pantai Baru dan Pantai Kuwaru. Dari peta tersebut terlihat sampai sejauh mana banjir rob yang menggenangi kedua kawasan pantai dan apa saja dampaknya terhadap fasilitas wisata yang ada di kedua daya tarik wisata tersebut. Hasil pemetaan banjr rob dan dampaknya terhadap fasilitas wisata di Pantai Baru dan Pantai Kuwaru dapat dilihat pada Gambar 5.

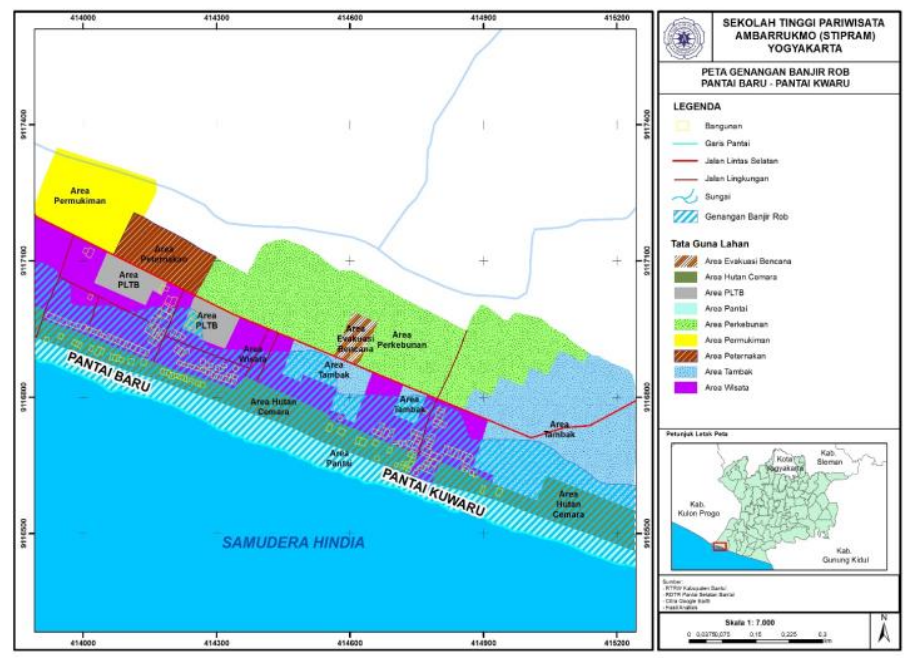

Gambar 5. Peta Sebaran Genangan Banjir Rob dan Dampaknya terhadap Fasilitas di Kawasan Pantai Baru dan Pantai Kuwaru

\section{Analisis Pengembangan Kawasan}

Setelah mengetahui karakteriktik kawasan dan ancaman genangan banjir rob, maka langkah selanjutnya perlu dilakukan analisis pengembangan kawasan. Analisis pengembangan kawasan ini menggunakan analisis SWOT, yaitu mengidentifikasi apa yang menjadi kekuatan (strength), kelemahan (weakness), peluang (opportunity), dan ancaman (threat). Dengan mengetahui keempat faktor tersebut diharapkan dapat dirumuskan strategi pengembangan dari Pantai Baru dan Pantai Kuwaru.

1. Strength/Kekuatan Kawasan Pantai Baru dan Kwaru

- Memiliki ciri khas habitat pohon cemara udang di sepanjang pesisir pantai.

- Memiliki potensi pariwisata alam (pantai) dan wisata edukasi (pembangkit listrik tenaga bayu di Pantai Baru).

- Merupakan salah satu destinasi utama pantai pesisir selatan Kabupaten Bantul.

- Memiliki jaringan aksesibilitas Kawasan berupa jalan yang menghubungkan antar daya tarik wisata pantai di wilayah pesisir pantai selatan.

2. Weakness/ Kelemahan Kawasan Pantai Baru dan Kwaru

- Pembangunan di dalam Kawasan berjalan secara sporadis tanpa adanya zoning yang jelas.

- Pembangunan di dalam Kawasan belum sepenuhnya memenuhi aspek mitigasi bencana air pasang (abrasi) dan banjir rob.

- Kesadaran masyarakat dalam menjaga kelestarian habitat hutan cemara udang di Pantai Kuwaru masih rendah.

\section{Opportunity/ Peluang Kawasan Pantai Baru dan Kwaru}

- Memiliki posisi strategis berada diantara deretan destinasi wisata pesisir pantai selatan Kabupaten Bantul, dan berada di sisi paling barat berdekatan dengan pintu masuk akses utama dari arah barat (Kulon Progo). 
- Kawasan pantai Kuwaru dan pantai Baru sudah dikenal sebagai destinasi utama pantai pesisir selatan Bantul sejak lama.

4. Threath/ Ancaman Kawasan Pantai Baru dan Kwaru

- Potensi bencana abrasi dan banjir rob pantai sangat tinggi.

- Potensi distribusi sampah wisatawan sangat tinggi, kesadaran akan menjaga kebersihan lingkungan masih rendah.

- Peluang usaha tambak udang di sekitar pesisir pantai selatan Bantul telah mempengaruhi pada perubahan ruang Kawasan dari Kawasan hijau (hutan cemara udang) menjadi Kawasan tambak udang.

\section{Rekomendasi Penataan Ruang Kawasan Pantai Baru dan Pantai Kuwaru}

Berdasarkan hasil analisis SWOT maka didapat strategi penataan ruang kawasan Pantai Baru dan Pantai Kuwaru sebagai berikut:

A. Strategi Strenght - Opportunities (S-O)

Strategi ini dibuat dengan memanfaatkan seluruh kekuatan untuk merebut dan memanfaatkan peluang, seperti:

1) Membuat perencanaan kawasan yang lebih tertata dengan memaksimalkan pemberdayaan potensi alami kawasan (habitat pohon cemara udang), serta potensi wisata edukasi PLTB di kawasan Pantai Baru.

2) Mengintegrasikan penataan Pantai Kuwaru dan Pantai Baru dengan memanfaatkan jaringan jalan yang sudah ada dan mengembangkan potensi jejaring jalan baru di dalam kawasan pesisir.

B. Strategi Weaknees - Opportunities (W-O)

Strategi ini dibuat dengan memanfaatkan peluang dengan meminimalkan kelemahan yang ada seperti:

3) Membuat perencanaan kawasan dengan zonasi yang lebih jelas dengan mempertimbangkan aspek mitigasi bencana abrasi serta peningkatan aspek perekonomian dan sosial budaya masyarakat setempat.

4) Menata Kawasan Pantai Kuwaru dan Pantai Baru yang lebih ramah wisatawan, sehingga dapat meningkatkan length of stay \& spending money wisatawan.

C. Strategi Strenght - Treaths (S-T)

Strategi ini dibuat dengan menggunakan kekuatan yang dimiliki untuk mengatasi ancaman yang ada, seperti:

5) Membuat perencanaan kawasan pembatasan yang jelas antara zona rawan bencana abrasi dan banjir rob dengan zona pembangunan fasilitas fisik, serta zonasi yang jelas untuk area usaha tambak udang.

6) Meningkatkan sarana-prasarana penampungan dan pengolahan sampah dan limbah yang dihasilkan dari aktivitas wisata.

D. Strategi Weaknees -Treaths (W-T)

Strategi ini didasarkan pada kegiatan yang bersifat defensif dan berusaha meminimalkan kelemahan yang ada serta menghindari ancaman, seperti:

7) Membuat perencanaan zonasi pembangunan fisik kawasan melalui building-code yang jelas sebagai upaya untuk memenuhi aspek mitigasi bencana dan perubahan fungsi lahan hijau, serta sebagai upaya perlindungan dan konservasi hutan cemara yang ada di dalam kawasan tersebut.

8) Mengembangkan sistem sarana - prasarana penunjang aktivitas wisata yang terpadu untuk meminimalisasi pencemaran lingkungan akibat limbah sampah wisatawan.

Pengurangan risiko bencana dapat dikategorikan menjadi tiga tahapan: 1) mengurangi atau membatasi ancaman terhadap bahaya; 2) mengurangi kerentanan berkaitan dengan bahaya; dan 3) meningkatkan kesiapsiagaan untuk mengantisipasi, menanggapi dan memulihkan diri dari ancaman bahaya sebuah bencana. Berdasarkan tingkat sebaran genangan banjir rob, maka direkomendasikan kawasan Pantai Baru dan Pantai Kuwaru dibagi ke dalam 3 zona yaitu zona I (Zona Pemanfaatan Terbatas), zona II (Zona Utama Wisata), dan zona III (Zona Pengembangan/Penunjang Wisata).

Zona I, merupakan zona terbatas yang tidak dianjurkan untuk dibangun bangunan permanen dan diarahkan sebagai zona wisata pantai, aktivitas rekreasi, dan surfing serta pos tim SAR. Zona II, ditetapkan sebagai zona utama wisata dan diarahkan untuk pengembangan zona ekowisata, wisata edukasi serta area untuk perkemahan dan wisata outbound. Zona III, ditetapkan sebagai zona penunjang wisata/ zona pengembangan, yang diarahkan untuk pengembangan sarana penunjang wisata seperti hotel/ penginapan, rumah makan, cafetaria, toko souvenir, gedung informasi/ pengelola wsata, pondok wisata, dan area parkir. Peta rekomendasi penataan ruang Kawasan Pantai Baru dan Pantai Kuwaru dapat dilihat pada Gambar 6.

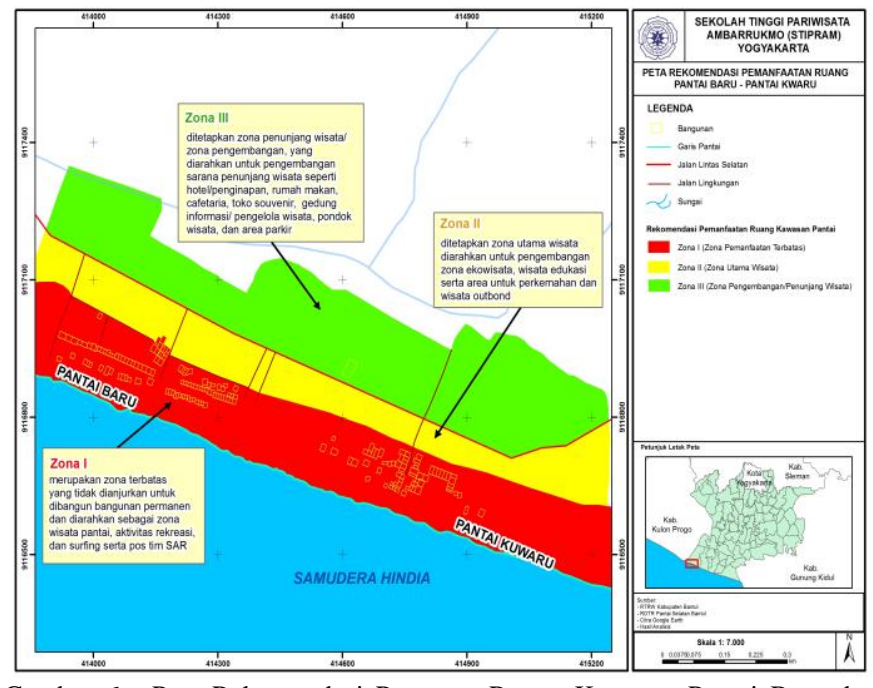

Gambar 6. Peta Rekomendasi Penataan Ruang Kawasan Pantai Baru dan Pantai Kuwaru

\section{PENUTUP}

\section{A. Simpulan}

Berdasarkan analisis dan pembahasan yang telah dilakukan, maka dapat diambil beberapa kesimpulan sebagai berikut:

1) Pantai Baru dan Pantai Kuwaru merupakan bagian dari 
kawasan Pantai Selatan Daerah Istimewa Yogyakarta yang memiliki potensi pariwisata yang besar dan juga merupakan pintu gerbang utama dari Samudera Hindia

2) Abad Samudera Hindia yang merupakan visi dari Gubernur DIY membuka peluang bagi pengembangan Pantai Baru dan Pantai Kuwaru

3) Pantai Baru dan Pantai Kuwaru memiliki ancaman bencana banjir rob yang menggenangi sebagian besar area utama kawasan wisata

4) Untuk menghindari banjir rob yang mengenai area kawasan wisata, maka diberikan rekomendasi pemanfaatan ruang berdasarkan hasil analisis banjir rob. Pemanfaatan Ruang kawasan wisata Pantai Baru dan Pantai Kuwaru terbagi mnejadi 3 zona yaitu: Zona I (Zona Pemanfaatan Terbatas), Zona II (Zona Utama Wisata), dan Zona III (Zona Pengembangan Wisata).

\section{B. Saran}

Beberapa saran yang diberikan berdasarkan hasil penelitian adalah:

1) Setelah diketahui bahwa kawasan pantai selatan khususnya Pantai Baru dan Pantai Kuwaru rawan terhadap banjir rob, maka pemerintah perlu mengambil tindakan strategi untuk mengurangi risiko bencana tersebut.

2) Hasil dari penelitian ini yang membagi kawasan pantai membagi 3 zona diharapkan dapat menjadi masukan bagi pemerintah atau pihak terkait dalam penerapan pengurangan risiki bencana.

3) Bagi penelitian selanjutnya, diharapkan dapat memberikan analisis yang lebih mendalam tentang analisis risiko bencana di kawasan pantai selatan serta memberi arahan strategi adaptasi dan mitigasi terhadap bencana alam banjir rob.

\section{UCAPAN TERIMA KASIH}

Penulis mengucapkan terima kasih kepada Direktorat Riset dan Pengabdian Masyarakat, Direktorat Jenderal Penguatan Riset dan Pengembangan, serta Kementerian Riset dan Teknologi dan Pendidikan Tinggi (Kemenristek-Dikti) Republik Indonesia yang telah memberikan hibah atau bantuan kepada penulis untuk melakukan penelitian ini melalui skema Penelitian Dosen Pemula (PDP).

\section{DAFTAR PUSTAKA}

[1] D. Pranita, "MEMBANGUN KAPABILITAS DAN STRATEGI KEBERLANJUTAN UNTUK MENINGKATKAN KEUNGGULAN BERSAING PARIWISATA BAHARI INDONESIA," $J$. Vokasi Indones., 2016, doi: 10.7454/jvi.v4i2.104.

[2] N. Kurniasari, "Strategi Penanganan Krisis Kepariwisataan dalam Kebijakan Badan Nasional Penanggulangan Bencana (BNPB)," Mediat. J. Komun., 2017, doi: 10.29313/mediator.v10i2.3007.

[3] K. W. Sayogi and A. Demartoto, "Pengembangan Wisata Bahari," $J$. Dev. Soc. Chang., 2018.

[4] F. Sidik, "Menggali Potensi Lokal Mewujudkan Kemandirian Desa," JKAP (Jurnal Kebijak. dan Adm. Publik), 2015, doi: 10.22146/jkap.7962.

[5] F. Ibrahim, F. Atriani, T. R. Wulan, M. D. Putra, and E. Maulana, "Upaya Pengurangan Risiko Bencana Terkait Perubahan Iklim Mitigasi Bencana Erosi Kepesisiran di Pantai Kuwaru dan Samas, Kabupaten
Bantul DIY," Pros. Semin. Nas. Geogr. UMS, 2016.

[6] D. Ardiyanti, "Indonesia sebagai Poros Maritim Dunia," Resolusi J. Sos. Polit., 2018.

[7] E. Rindrasih, P. Witte, T. Spit, and A. Zoomers, "Tourism and Disasters: Impact of Disaster Events on Tourism Development in Indonesia 1998-2016 and Structural Approach Policy Responses," J. Serv. Sci. Manag., 2019, doi: 10.4236/jssm.2019.122006.

[8] R. Rahmad, "Penilaian Kerentanan dan Kesiapsiagaan Bencana Tsunami di Pesisir Sadeng, Gunungkidul," J. Geogr., 2019, doi: 10.24114/jg.v11i2.11475.

[9] P. D. Sugiyono, metode penelitian kuantitatif, kualitatif,dan $R \& D$. 2016.

[10] M. Mercieca, F. Schembri, A. S. Inglott, and L. M. Azzopardi, "Swot analysis," Pharmaceutical Technology. 2016, doi: 10.4337/9781784712082.00015.

[11] BNPB, "Potensi dan Ancaman Bencana," BNPB, 2017. 